\title{
Interleukin 6 Measurement
}

National Cancer Institute

\section{Source}

National Cancer Institute. Interleukin 6 Measurement. NCI Thesaurus. Code C74834.

The determination of the amount of interleukin 6 present in a sample. 